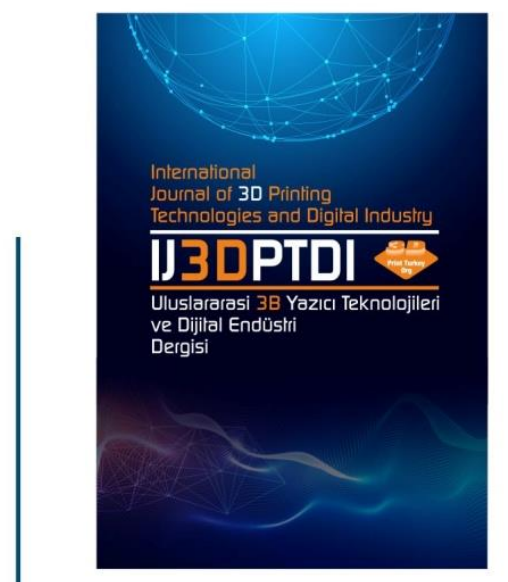

ULUSLARARASI 3B YAZICI TEKNOLOJILERI

VE DIJITAL ENDÜSTRI DERGISI

INTERNATIONAL JOURNAL QF 30 PRINTING TECHNOLOGIES AND DIGITAL INDUSTRY

ISSN:2602-3350 [Online]

URL: https://dergipark.org.tr/ij3dptdi

\title{
APPLICATION AND COMPARISON OF TOPOLOGY OPTIMIZATION FOR ADDITIVE MANUFACTURING AND MACHINING METHODS
}

Yazarlar (Authors): Ahu Çelebi ${ }^{*}$, Halil Tosun (D)

Bu makaleye şu şekilde atıfta bulunabilirsiniz (To cite to this article): Çelebi A., Tosun A. "Application And Comparison Of Topology Optimization For Additive Manufacturing And Machining Methods", Int. J. of 3D Printing Tech. Dig. Ind., 5(3): 676691, (2021). 


\title{
APPLICATION AND COMPARISON OF TOPOLOGY OPTIMIZATION FOR ADDITIVE MANUFACTURING AND MACHINING METHODS
}

\author{
Ahu Çelebi a (iD**, Halil Tosun a,biD \\ ${ }^{a}$ Metalurji ve Malzeme Mühendisliği Departmanı, Celâl Bayar Üniversitesi, Manisa, Türkiye \\ ${ }^{b}$ ESHOT Genel Müdürlüğü, İzmir, Türkiye \\ *Corresponding author: ahu.celebi@cbu.edu.tr
}

(Received: 10.06.2021; Revised: 19.10.2021; Accepted: 28.12.2021)

\begin{abstract}
Thanks to the developing technology and softwares, analysis and optimization of the engineering parts can be done through computer programs nowadays. Softwares play an active role not only in analysis but also in reducing the material cost as a result of lightening the part with changes in design. Manufacturing methods and comparisons of these methods with each other have always been the subject of research. Choosing the methods of manufacturing of material has a great importance for enterprise. The loads and strength of the designed part under operating conditions are very important for the manufacturer. The pros and cons of both production methods which are additive manufacturing and machining have been investigated and these methods have been compared for the use of Pet-G material. A FDM (Fused Deposition Modeling) type 3D (three-dimensional) printer has been used in the additive manufacturing method and CNC Router (Computer Numerical Control Router) has been used for the machining method. A part design created in accordance with the mentioned manufacturing methods and its mechanical properties after its twice optimization have been examined and compared. After the optimizations, the targeted reduction on the mass of production has been achieved. After the optimization process, the sample has reduced by about $63 \%$ in volume and mass according to the design program. The mass of the sample, which is approximately 300 grams, has been reduced to 100 grams. As a result of the tests, it has been observed that the strength values of the samples manufactured by machining are higher.
\end{abstract}

Key words : Design Optimization, Topology Optimization, Additive Manufacturing, Machining, 3D Printer

\section{INTRODUCTION}

Machining, which is one of the traditional manufacturing methods, parts having many different designs can be manufactured nowadays [1,2], however, with the developing technology, additive manufacturing methods have start to become an alternative to machining methods due to printing parts of complex geometries that cannot be produced by standard technologies. While machining are based on material reduction, additive manufacturing works in the opposite way. This ensures that waste rates are reduced or eliminated. In addition, the elimination of constraints in design is the greatest advantage of additive manufacturing methods. However, the ability to manufacture super finished surfaces [3-5].

Engineers have to create optimum designs by using their technical knowledge and experience, taking into account many factors such as material, cost, technology, environmental conditions, functionality, ergonomics, etc. in their designs [6,7]. Therefore, today, a part or construction designed by an engineer must also be an optimization activity. 


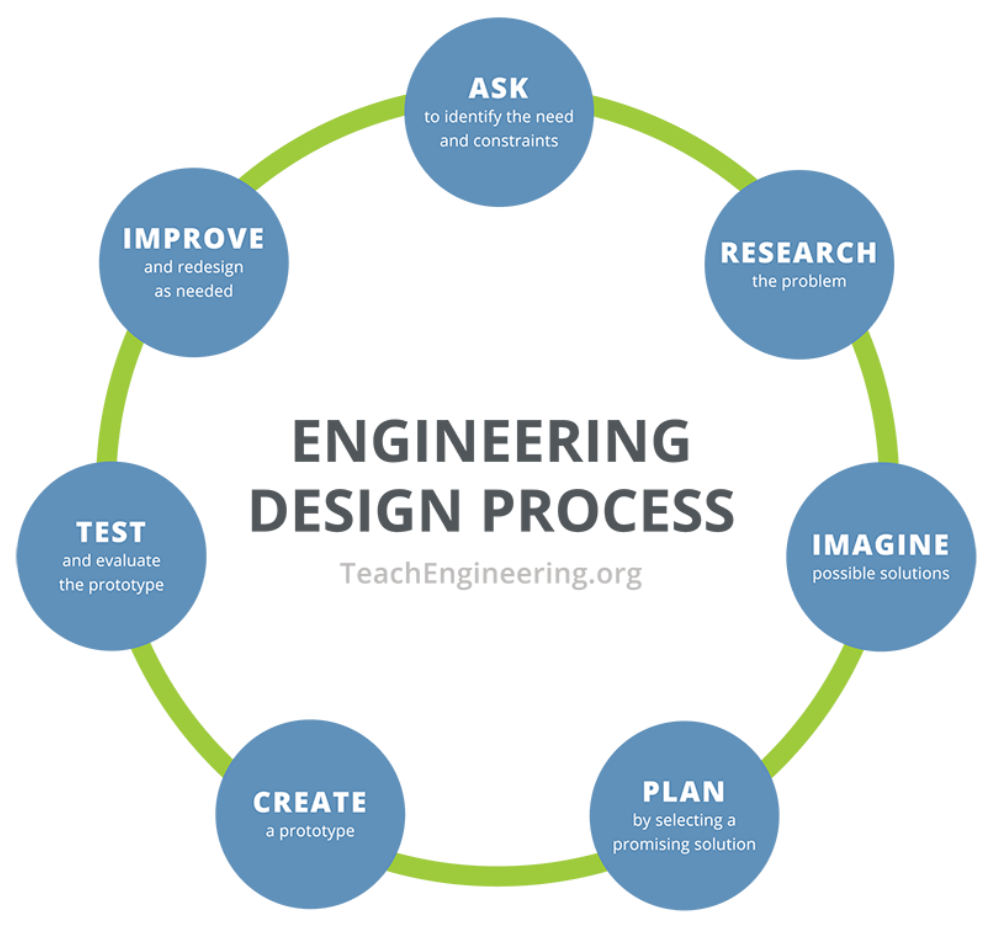

Figure 1. Effects and constraints during design and development [8].

Although there are many restrictive factors during the design process, the use of software facilitates the work of designers and accelerates the design process. Today, designers accelerate their designs with computer-aided design (CAD) and finite element analysis (FEA) software and can perform simulation and optimization processes [8-10]. With topology optimization software, designs that can not be manufactured by conventional methods but can be manufactured by additive manufacturing (3D printers) can be designed and manufactured. As an example, the results of different iterations of a satellite bracket can be seen in Figure 2 [11]. The another important advantage of topology optimization is that it can reduce costs by saving material with the final design. As an example, Figure 3 shows two different designs obtained by Çalı̧̧kan as a result of different optimizations of a part of a commercial vehicle [12-14].

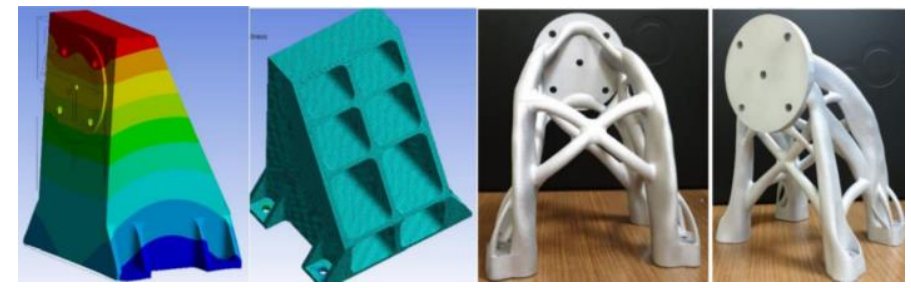

Figure 2. Satellite bracket optimization [11].
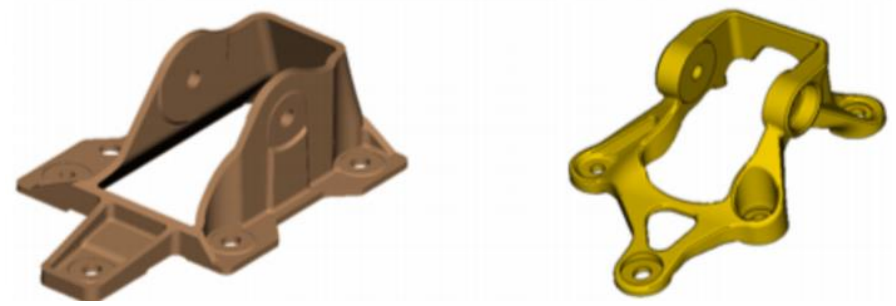

Figure 3. A part lightened by optimization [13].

As can be seen, minimum wastage due to the nature of additive manufacturing, and mass reduction in the final design thanks to optimization provide a good combination from design to manufacturing. In this study, the mentioned combination is made and topology optimization is applied on a part design 
that can be manufactured by both additive manufacturing and machining. In the application, an FDM type printer and 3-axis CNC router have been used. The designed samples have been manufactured for both before and after optimization and they have been compared under tensile load. In the optimization process, the specifications of the plate to be used for the machining have been taken from the manufacturer of it and the specifications of the tensile samples produced in the printer have been used. PET-G materials have been used in both methods, but due to the nature of the manufacturing methods, material in sheet form has been used in machining, while in additive manufacturing, material in filament form has been used. Autodesk Inventor program has been used for Computer Aided Design (CAD), and topology optimization applications have been also carried out with this software. The software in question has been preferred because it contains the necessary tools for both design, analysis and optimization. After the design, analysis and optimization steps, the parts obtained by additive manufacturing and machining have been tested by the tensile test machine and the results obtained were compared with the analysis and simulations. Details of the applications are given in Chapter 2.

\section{APPLICATIONS}

As a first step in the design, a conceptual model to be exposed to tensile loads and to be manufactured from PET-G material was prepared with the CAD design software. Attention has been paid to the fact that the conceptual model can be produced by both machining and additive manufacturing (to 3D printer) methods in order to be able to make comparisons. Then, the load to be carried has taken into consideration, the material properties have been given to the software, and linear FEA (Finite Element Analysis) and topology optimization has been carried out, respectively. The entire design and optimization process have been carried out using the Autodesk Inventor 2020 software. After the design and optimization, the part is required not to be failure and to have stress values below the yield stress value while carrying load. Whether this is achieved or not has been checked with the FEA method before and after each optimization step. Since the topology optimization is carried out on a mesh model based on the solid model design, the design has been finalized by creating a solid model again over the new mesh model formed at the end of the optimization. Before the manufacturing, it has been confirmed with FEA that there is no failure and then the manufacturing has been carried out. Optimization process has been carried out twice, and after each optimization, the same solid model has been designed for both machining and additive manufacturing. In other words, all conceptual design and optimized design measures are the same for both methods. Figure 4 shows the work flow for the operations performed in the application. The conceptual model shown in Figure 5 has been designed by inspiring from a previously used part in automotive industry.

The mechanical properties of Pet-G material to be used in machining which was taken from its manufacturer have been entered into the software. For additive manufacturing, the technical properties of the material have been obtained by creating tensile test samples to determine the mechanical properties. For the determination of filament mechanical properties, ASTM D638 standard has been examined and 5 pieces of tensile test samples have been prepared in accordance with the type I sample dimensions from the sample types included in this standard. The mentioned samples and their dimensions are shown in Figure 6.

The tests have been carried out with the AUTOGRAPH brand AG-IS 100KN model tensile test machine which is in the laboratory of the Faculty of Engineering at Manisa Celal Bayar University. In the design software, the plate properties and tensile test results to be used for the conceptual model have been entered and the analysis has been made. The yield strength value for machining has been entered into the program as $52 \mathrm{MPa}$. For additive manufacturing, the value of $29 \mathrm{MPa}$ obtained from the tensile test has been used. As seen in Figure 7, the lower two holes have been marked as fixed support. A force of $2000 \mathrm{~N}$ for the upper hole to the upward and the gravity force have been applied downward direction. 


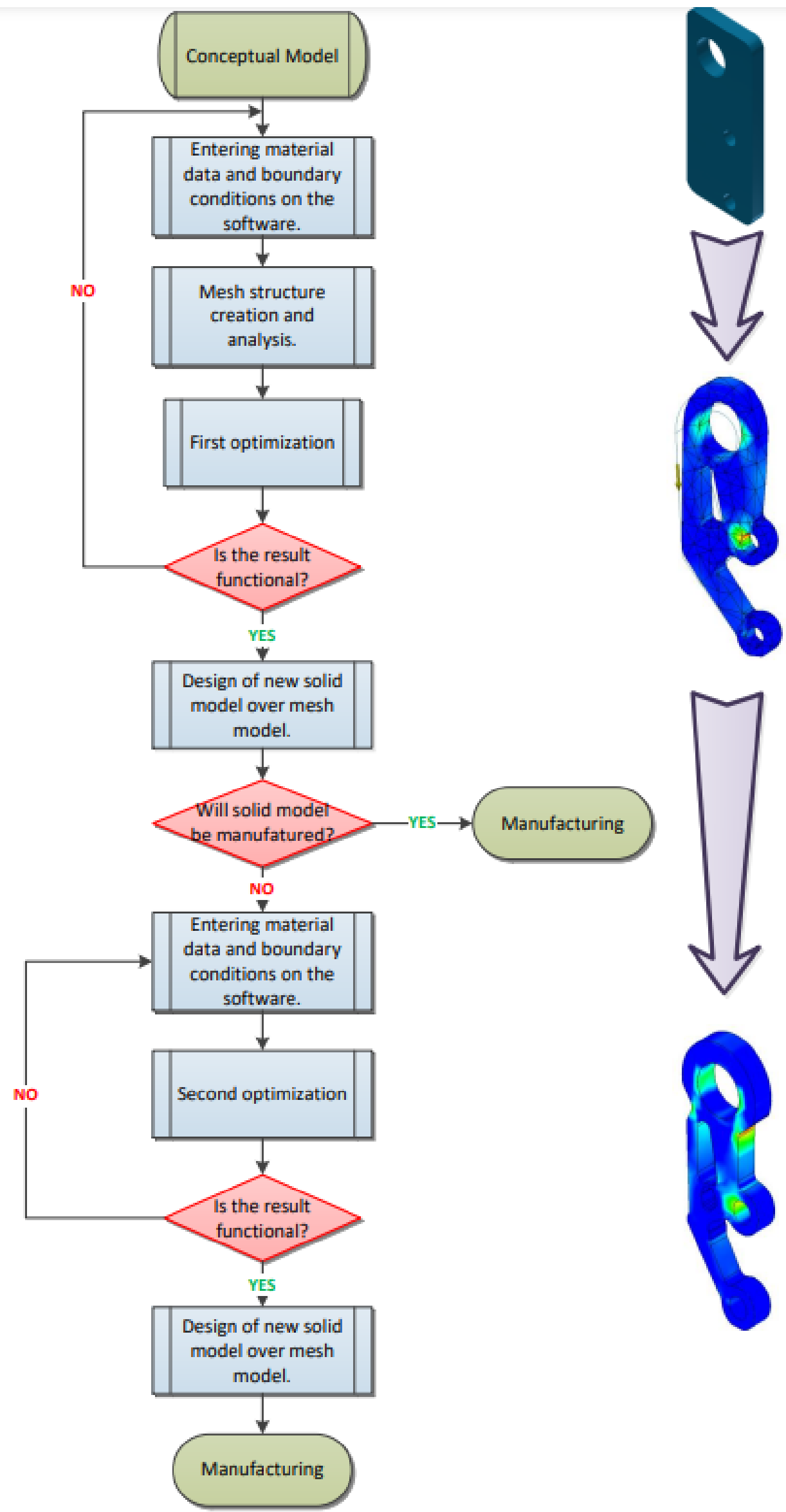

Figure 4. Workflow of Optimization 

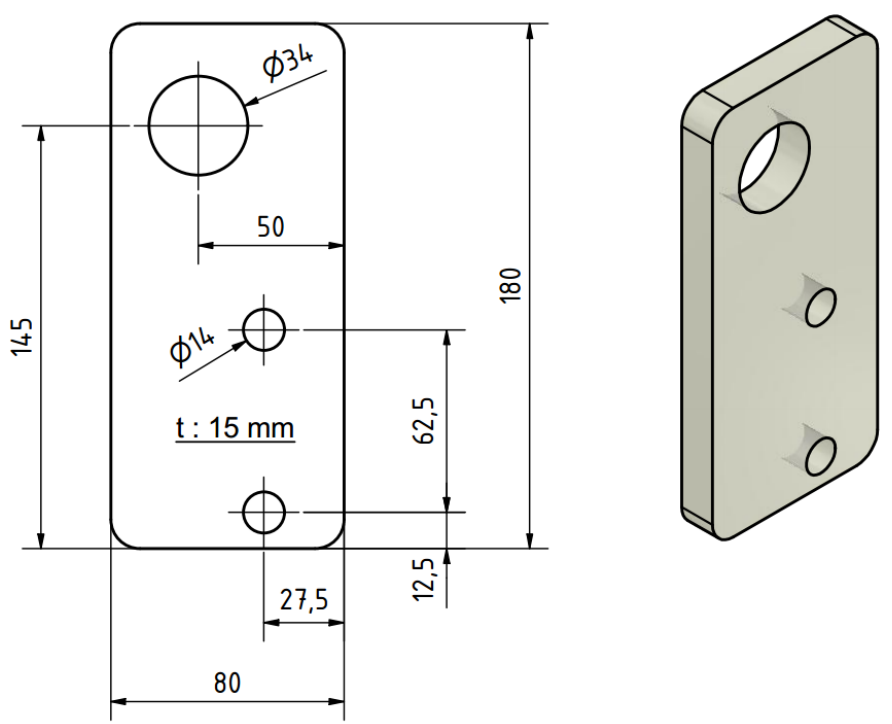

Figure 5. Conceptual model measurements.

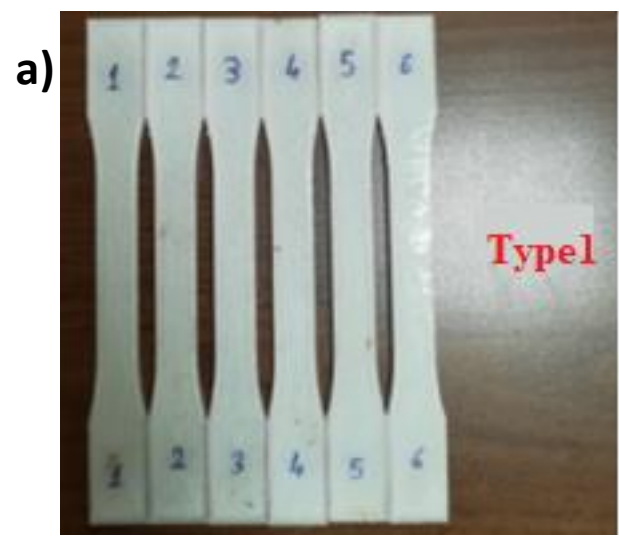

b)

Figure 6. a) Tensile test samples, b) dimensions of tensile test samples

Table 1. Test results of Type I tensile specimens.

\begin{tabular}{|c|c|c|c|}
\hline $\begin{array}{c}\text { ASTM D638 TYPE1 TENSILE } \\
\text { TEST RESULTS }\end{array}$ & $\begin{array}{c}\text { MAXIMUM } \\
\text { TENSILE } \\
\text { MPa }\end{array}$ & $\begin{array}{c}\text { MAXIMUM } \\
\text { FORCE } \\
\text { kN }\end{array}$ & $\begin{array}{c}\text { ELASTICITY } \\
\text { MODULE } \\
\text { MPa }\end{array}$ \\
\hline TYPE1-1 & 28.095 & 1.117 & 1957.210 \\
\hline TYPE1-3 & 29.597 & 1.231 & 2337.740 \\
\hline TYPE1-4 & 31.700 & 1.319 & 1451.660 \\
\hline TYPE1-5 & 30.574 & 1.272 & 1570.040 \\
\hline TYPE1-6 & 28.921 & 1.203 & 1382.340 \\
\hline Average & 29.778 & 1.228 & 1739.798 \\
\hline Standard Deviation & 1.259 & 0.068 & 359.004 \\
\hline \%5 for t (\% 68) Distribution Value & 1.110 & 1.110 & 1.110 \\
\hline \%95 for ' ' Value & 2 & 2 & 2 \\
\hline \%95 Minimum Reliability & 26.982 & 1.077 & 942.809 \\
\hline
\end{tabular}




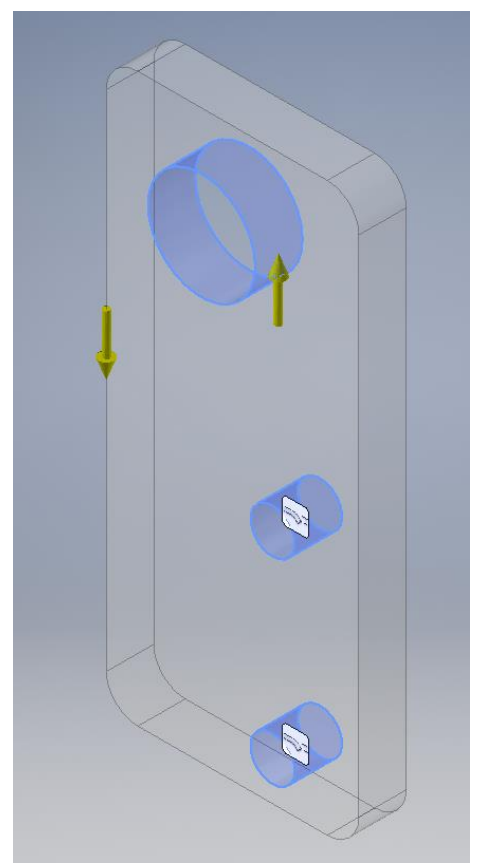

Figure 7. Representation of supports and forces.

Mesh settings during the analysis are given in Fig.8. While performing static analysis and optimization, the minimum element size was chosen as $0.2 \mathrm{~mm}$ and the angle between the mesh as $30^{\circ}$.

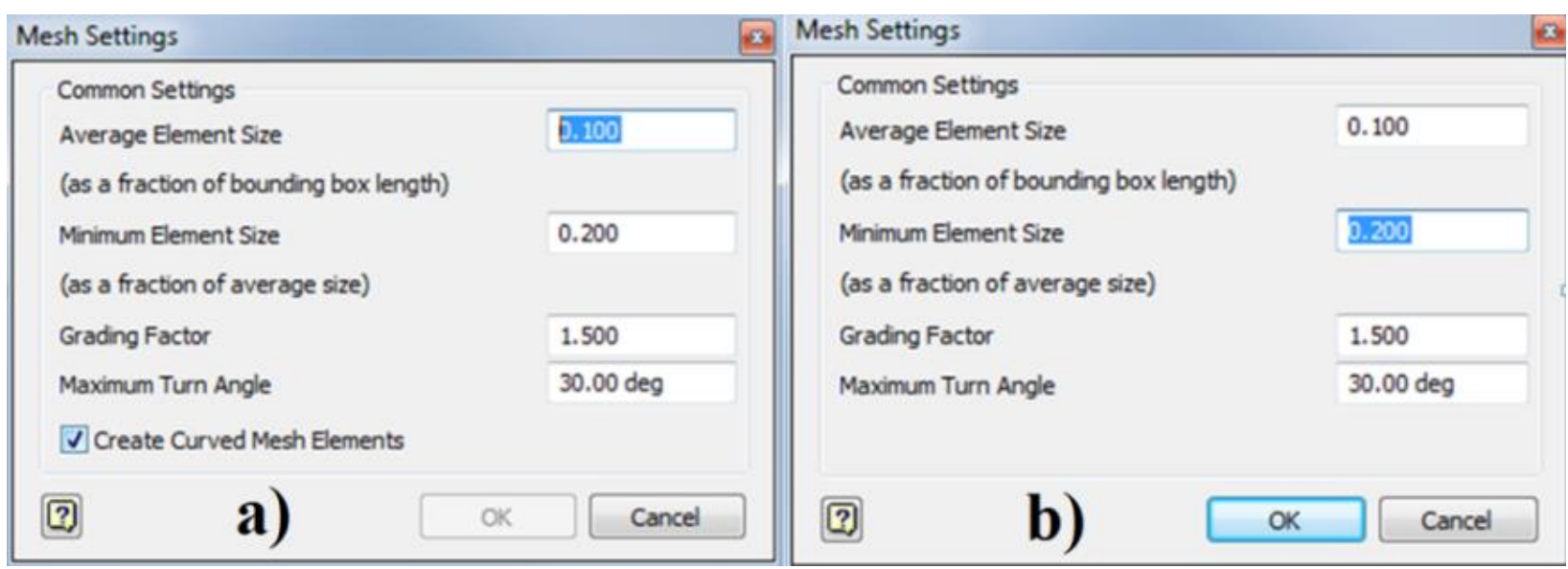

Figure 8. Mesh settings for a) static analysis b) optimization

The number of elements and nodes formed in the analysis performed are shown in Table 2.

Table 2. Mesh properties after selected settings.

\begin{tabular}{|l|c|c|}
\cline { 2 - 3 } \multicolumn{1}{c|}{} & NODES & ELEMENTS \\
\hline Before Optimization & 5353 & 3058 \\
\hline First Optimization & 5381 & 3079 \\
\hline Before First Analysis & 5679 & 3190 \\
\hline Second Optimization & 5773 & 3255 \\
\hline Before Second Analysis & 8747 & 5030 \\
\hline
\end{tabular}


First, the conceptual design has been exposed to static loads using the "Stress Analysis" module of the software. With the static analysis, it has been determined whether the conceptual design can carry the given loads or not. Afterwards, the following operations have been carried out, respectively:

- first optimization step,

- Finite element analysis after first optimization,

- second optimization step,

- Finite element analysis after second optimization

\subsection{Optimization Process}

\subsubsection{Pre-Optimization Finite Element Analysis}

In the design software, the plate and filament properties to be used for the conceptual model have been entered and the analysis has been started. Von Mises hypothesis is the best performing and most widely used calculation method for ductile materials. In a multiaxial stress situation, it uses a single value representing these and this stress is called the Von Mises stress. If this stress exceeds the yield strength in the tensile test of the material, failure occurs [15-18]. Von Mises stresses on the conceptual design can be seen in Figure 9.

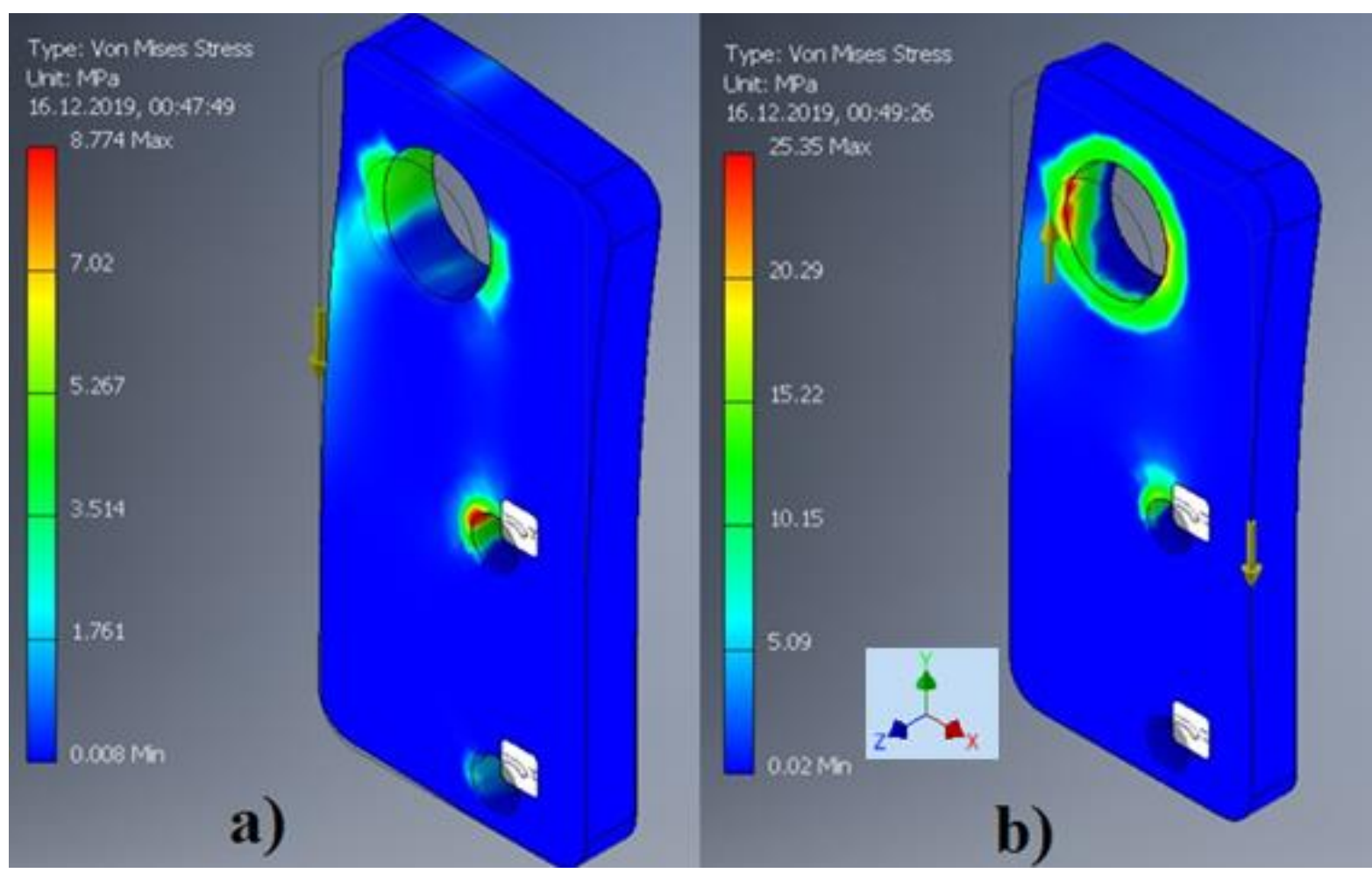

Figure 9. Von Mises stresses in finite element analysis before optimization a) machining b) additive manufacturing

On the conceptual design (before optimization), after the first static analysis made with the software, it has been observed that there are regions exposed to a maximum stress of $8.77 \mathrm{MPa}$ on the specimen to be manufactured by machining and $25.35 \mathrm{MPa}$ on the specimen to be manufactured by additive manufacturing. These values can be reached as minimum and maximum from the Von Mises Stress line in Table 3. 
Table 3. Analysis results before optimization.

MACHINING ANALYSIS RESULTS

\begin{tabular}{|l|c|c|}
\hline Name & Minimum & Maximum \\
\hline Volume & $196409 \mathrm{~mm}^{\wedge} 3$ & \\
\hline Mass & $0.303 \mathrm{~kg}$ & \\
\hline Von Mises Stress & $0.008 \mathrm{MPa}$ & $8.774 \mathrm{MPa}$ \\
\hline 1st Principal Stress & $-1.217 \mathrm{MPa}$ & $9.404 \mathrm{MPa}$ \\
\hline 3rd Principal Stress & $-5.992 \mathrm{MPa}$ & $1.719 \mathrm{MPa}$ \\
\hline Displacement & $0.000 \mathrm{~mm}$ & $0.327 \mathrm{~mm}$ \\
\hline Safety Factor & $5.927 \mathrm{ul}$ & $15.000 \mathrm{ul}$ \\
\hline Stress XX & $-3.491 \mathrm{MPa}$ & $3.789 \mathrm{MPa}$ \\
\hline Stress XY & $-4.254 \mathrm{MPa}$ & $2.415 \mathrm{MPa}$ \\
\hline Stress XZ & $-0.960 \mathrm{MPa}$ & $1.135 \mathrm{MPa}$ \\
\hline Stress YY & $-5.105 \mathrm{MPa}$ & $8.562 \mathrm{MPa}$ \\
\hline Stress YZ & $-1.725 \mathrm{MPa}$ & $1.716 \mathrm{MPa}$ \\
\hline Stress ZZ & $-2.667 \mathrm{MPa}$ & $4.180 \mathrm{MPa}$ \\
\hline X Displacement & $-0.019 \mathrm{~mm}$ & $0.288 \mathrm{~mm}$ \\
\hline Y Displacement & $-0.033 \mathrm{~mm}$ & $0.214 \mathrm{~mm}$ \\
\hline Z Displacement & $-0.009 \mathrm{~mm}$ & $0.009 \mathrm{~mm}$ \\
\hline Equivalent Strain & $0.000 \mathrm{ul}$ & $0.004 \mathrm{ul}$ \\
\hline 1st Principal Strain & $0.000 \mathrm{ul}$ & $0.004 \mathrm{ul}$ \\
\hline 3rd Principal Strain & $-0.004 \mathrm{ul}$ & $-0.000 \mathrm{ul}$ \\
\hline Strain XX & $-0.003 \mathrm{ul}$ & $0.002 \mathrm{ul}$ \\
\hline Strain XY & $-0.003 \mathrm{ul}$ & $0.002 \mathrm{ul}$ \\
\hline Strain XZ & $-0.000 \mathrm{ul}$ & $0.000 \mathrm{ul}$ \\
\hline Strain YY & $-0.002 \mathrm{ul}$ & $0.004 \mathrm{ul}$ \\
\hline Strain YZ & $-0.001 \mathrm{ul}$ & $0.001 \mathrm{ul}$ \\
\hline Strain ZZ & $-0.001 \mathrm{ul}$ & $0.000 \mathrm{ul}$ \\
\hline
\end{tabular}

ADDITIVE MANUFACTURING ANALYS IS RES ULTS

\begin{tabular}{|l|c|c|}
\hline Name & Minimum & Maximum \\
\hline Volume & $196409 \mathrm{~mm}^{\wedge} 3$ & \\
\hline Mass & $0.303 \mathrm{~kg}$ & \\
\hline Von Mises Stress & $0.024 \mathrm{MPa}$ & $25.351 \mathrm{MPa}$ \\
\hline 1st Principal Stress & $-6.588 \mathrm{MPa}$ & $36.626 \mathrm{MPa}$ \\
\hline 3rd Principal Stress & $-19.148 \mathrm{MPa}$ & $12.725 \mathrm{MPa}$ \\
\hline Displacement & $0.000 \mathrm{~mm}$ & $2.049 \mathrm{~mm}$ \\
\hline Safety Factor & $1.144 \mathrm{ul}$ & $15.000 \mathrm{ul}$ \\
\hline Stress XX & $-10.719 \mathrm{MPa}$ & $16.798 \mathrm{Mpa}$ \\
\hline Stress XY & $-9.846 \mathrm{MPa}$ & $10.065 \mathrm{MPa}$ \\
\hline Stress XZ & $-3.146 \mathrm{MPa}$ & $4.461 \mathrm{MPa}$ \\
\hline Stress YY & $-18.817 \mathrm{MPa}$ & $32.553 \mathrm{MPa}$ \\
\hline Stress YZ & $-8.002 \mathrm{MPa}$ & $8.080 \mathrm{MPa}$ \\
\hline Stress ZZ & $-8.659 \mathrm{Mpa}$ & $20.727 \mathrm{MPa}$ \\
\hline X Displacement & $-0.031 \mathrm{~mm}$ & $0.327 \mathrm{~mm}$ \\
\hline Y Displacement & $-0.227 \mathrm{~mm}$ & $0.486 \mathrm{~mm}$ \\
\hline Z Displacement & $-1.986 \mathrm{~mm}$ & $0.099 \mathrm{~mm}$ \\
\hline Equivalent Strain & $0.000 \mathrm{ul}$ & $0.013 \mathrm{ul}$ \\
\hline 1st Principal Strain & $0.000 \mathrm{ul}$ & $0.013 \mathrm{ul}$ \\
\hline 3rd Principal Strain & $-0.009 \mathrm{ul}$ & $-0.000 \mathrm{ul}$ \\
\hline Strain XX & $-0.005 \mathrm{ul}$ & $0.003 \mathrm{ul}$ \\
\hline Strain XY & $-0.007 \mathrm{ul}$ & $0.008 \mathrm{ul}$ \\
\hline Strain XZ & $-0.002 \mathrm{ul}$ & $0.003 \mathrm{ul}$ \\
\hline Strain YY & $-0.008 \mathrm{ul}$ & $0.011 \mathrm{ul}$ \\
\hline Strain YZ & $-0.006 \mathrm{ul}$ & $0.006 \mathrm{ul}$ \\
\hline Strain ZZ & $-0.005 \mathrm{ul}$ & $0.006 \mathrm{ul}$ \\
\hline
\end{tabular}

\subsubsection{First Optimization Step}

Optimization steps are performed under the "Shape Generator" module of the program. In optimization, first the material is defined and then the constraints are entered. The constraints entered through the software interface have been determined during optimization as " do not approach the lower two holes more than $12.5 \mathrm{~mm}$ and the upper hole more than $25 \mathrm{~mm}$ ". In addition, the software has been asked to make an optimization $60 \%$ lighter than the conceptual design mass. These entered constraints are shown in Figure 10. After these constraints entered in the program, the part has been meshed and analyzed again according to the mesh settings accepted during static analysis.

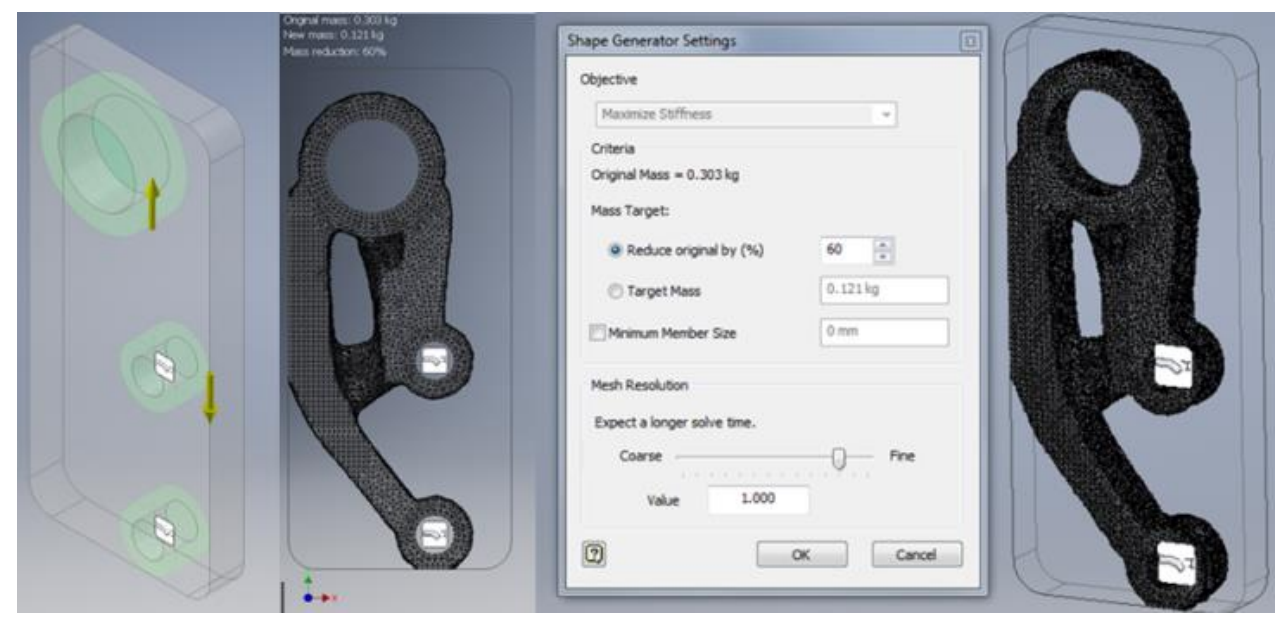

Figure 10. Entering constraints for first optimization from the software interface. 
After the first optimization process, the result of the optimization has been taken back to the sketch environment and the first optimized design drawing has been made. The first optimized part design is shown as yellow in Figure 11.

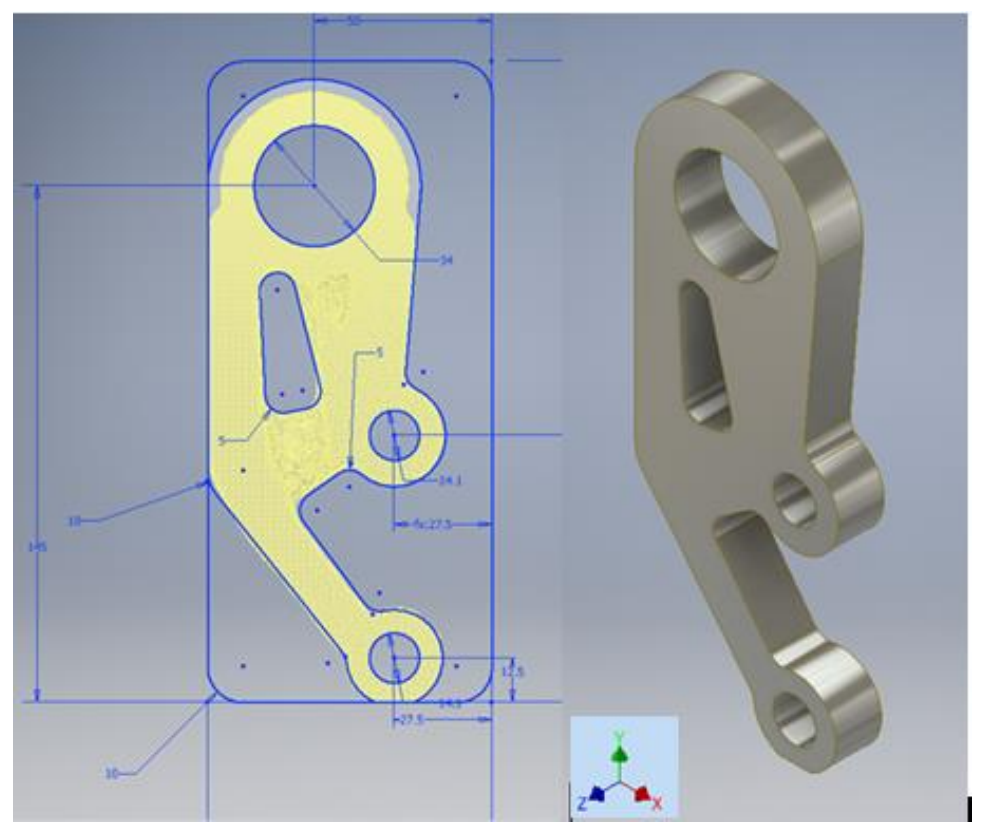

Figure 11. First optimization result.

\subsubsection{Finite Element Analysis After First Optimization}

As a result of the first optimization obtained, the part has been analysed again with the static analysis module of the software, after the material information, loads and supports have been entered into the software in the same way. As a result of this analysis, the results shown in Table 4 have been obtained.

Table 4. Analysis results after first optimization.

\begin{tabular}{|c|c|c|c|c|c|}
\hline \multicolumn{3}{|c|}{ MACHINING ANALYSIS RESULTS } & \multicolumn{3}{|c|}{ ADDITIVE MANUFACTURING ANALYS IS RESULTS } \\
\hline Name & Minimum & Maximum & Name & Minimum & Maximum \\
\hline Volume & $90612 \mathrm{~mm}^{\wedge} 3$ & & Volume & $90612 \mathrm{~mm}^{\wedge} 3$ & \\
\hline Mass & $0.140 \mathrm{~kg}$ & & Mass & $0.140 \mathrm{~kg}$ & \\
\hline Von Mises Stress & $0.008 \mathrm{MPa}$ & $14.120 \mathrm{MPa}$ & Von Mises Stress & $0.0107 \mathrm{MPa}$ & $14.013 \mathrm{MPa}$ \\
\hline 1st Principal Stress & $-0.921 \mathrm{MPa}$ & $12.916 \mathrm{MPa}$ & 1st Principal Stress & $-1.135 \mathrm{MPa}$ & $11.166 \mathrm{MPa}$ \\
\hline 3rd Principal Stress & $-8.246 \mathrm{MPa}$ & $3.655 \mathrm{Mpa}$ & 3rd Principal Stress & $-8.318 \mathrm{MPa}$ & $2.333 \mathrm{MPa}$ \\
\hline Displacement & $0.000 \mathrm{~mm}$ & $0.446 \mathrm{~mm}$ & Displacement & $0.000 \mathrm{~mm}$ & $0.447 \mathrm{~mm}$ \\
\hline Safety Factor & $3.683 \mathrm{ul}$ & $15.000 \mathrm{ul}$ & Safety Factor & $3.710 \mathrm{ul}$ & $15.000 \mathrm{ul}$ \\
\hline Stress XX & $-5.520 \mathrm{MPa}$ & $5.702 \mathrm{MPa}$ & Stress XX & $-5.880 \mathrm{MPa}$ & $4.418 \mathrm{MPa}$ \\
\hline Stress XY & $-6.322 \mathrm{MPa}$ & $3.521 \mathrm{MPa}$ & Stress XY & $-6.473 \mathrm{MPa}$ & $3.454 \mathrm{MPa}$ \\
\hline Stress XZ & $-2.240 \mathrm{MPa}$ & $1.926 \mathrm{MPa}$ & Stress XZ & $-1.587 \mathrm{MPa}$ & $1.585 \mathrm{MPa}$ \\
\hline Stress YY & $-5.166 \mathrm{MPa}$ & $12.061 \mathrm{MPa}$ & Stress YY & $-4.758 \mathrm{MPa}$ & $10.867 \mathrm{MPa}$ \\
\hline Stress YZ & $-2.339 \mathrm{MPa}$ & $2.176 \mathrm{MPa}$ & Stress YZ & $-1.919 \mathrm{MPa}$ & $1.928 \mathrm{MPa}$ \\
\hline Stress ZZ & $-2.579 \mathrm{MPa}$ & $5.720 \mathrm{MPa}$ & Stress ZZ & $-2.299 \mathrm{MPa}$ & $3.136 \mathrm{MPa}$ \\
\hline $\mathrm{X}$ Displacement & $-0.019 \mathrm{~mm}$ & $0.352 \mathrm{~mm}$ & X Displacement & $-0.019 \mathrm{~mm}$ & $0.352 \mathrm{~mm}$ \\
\hline Y Displacement & $-0.008 \mathrm{~mm}$ & $0.307 \mathrm{~mm}$ & Y Displacement & $-0.008 \mathrm{~mm}$ & $0.308 \mathrm{~mm}$ \\
\hline Z Displacement & $-0.011 \mathrm{~mm}$ & $0.011 \mathrm{~mm}$ & Z Displacement & $-0.012 \mathrm{~mm}$ & $0.012 \mathrm{~mm}$ \\
\hline Equivalent Strain & $0.000 \mathrm{ul}$ & $0.007 \mathrm{ul}$ & Equivalent Strain & $0.000 \mathrm{ul}$ & $0.006 \mathrm{ul}$ \\
\hline 1st Principal Strain & $0.000 \mathrm{ul}$ & $0.007 \mathrm{ul}$ & 1st Principal Strain & $0.000 \mathrm{ul}$ & $0.006 \mathrm{ul}$ \\
\hline 3rd Principal Strain & $-0.006 \mathrm{ul}$ & $-0.000 \mathrm{ul}$ & 3rd Principal Strain & $-0.006 \mathrm{ul}$ & $-0.000 \mathrm{ul}$ \\
\hline Strain $\mathrm{XX}$ & $-0.005 \mathrm{ul}$ & $0.002 \mathrm{ul}$ & Strain XX & $-0.005 \mathrm{ul}$ & $0.002 \mathrm{ul}$ \\
\hline Strain XY & $-0.005 \mathrm{ul}$ & $0.003 \mathrm{ul}$ & Strain XY & $-0.005 \mathrm{ul}$ & $0.003 \mathrm{ul}$ \\
\hline Strain XZ & $-0.002 \mathrm{ul}$ & $0.001 \mathrm{ul}$ & Strain XZ & $-0.001 \mathrm{ul}$ & $0.001 \mathrm{ul}$ \\
\hline Strain YY & $-0.002 \mathrm{ul}$ & $0.006 \mathrm{ul}$ & Strain YY & $-0.002 \mathrm{ul}$ & $0.006 \mathrm{ul}$ \\
\hline Strain YZ & $-0.002 \mathrm{ul}$ & $0.002 \mathrm{ul}$ & Strain YZ & $-0.001 \mathrm{ul}$ & $0.001 \mathrm{ul}$ \\
\hline Strain ZZ & $-0.002 \mathrm{ul}$ & $0.001 \mathrm{ul}$ & Strain ZZ & $-0.002 \mathrm{ul}$ & $0.001 \mathrm{ul}$ \\
\hline
\end{tabular}




\subsubsection{Second Optimization Step}

At this stage, restrictions have been entered into the software again. The biggest constraint and target here is to reduce the mass of the part material. For this, as seen in Figure 12, the material constraint has been entered as $0.1 \mathrm{~kg}$ (100 grams) via the "target mass" option. The appearance of the part obtained as a result of iterations is shown in yellow in figure 12. The final design has been drawn in the software over the yellow colour optimization result.

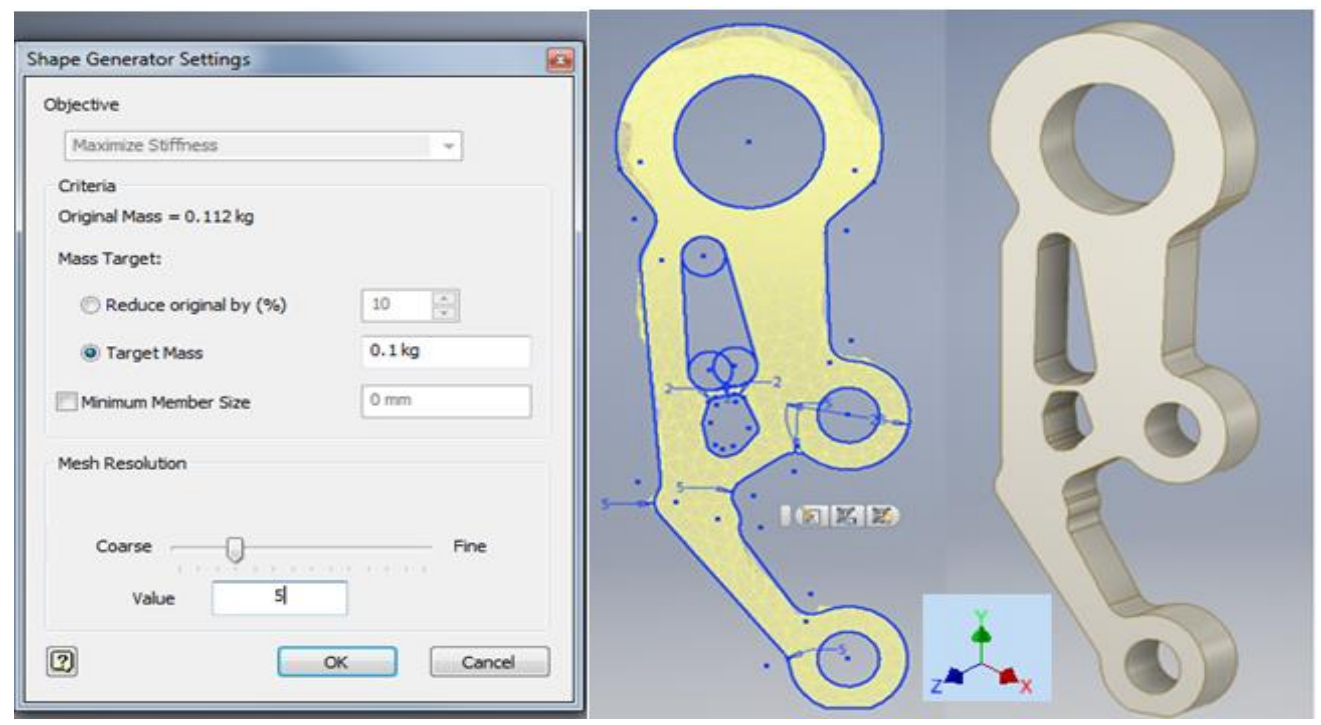

Figure 12. Final state of the part after optimization.

\subsubsection{Finite Element Analysis After Second Optimization}

As a result of the iterations made over the conceptual design, the sample shape shown in figure 13 was obtained. Regarding the final state of the part obtained as a result of the repetition of the optimizations, the regional maximum and minimum displacement amounts are given in this way. As can be understood from this figure given in millimetres, the most displacement occurs around the upper diameter where the force is applied. As a result of the analysis, it is predicted that the places where the samples are also broken will be in these regions.

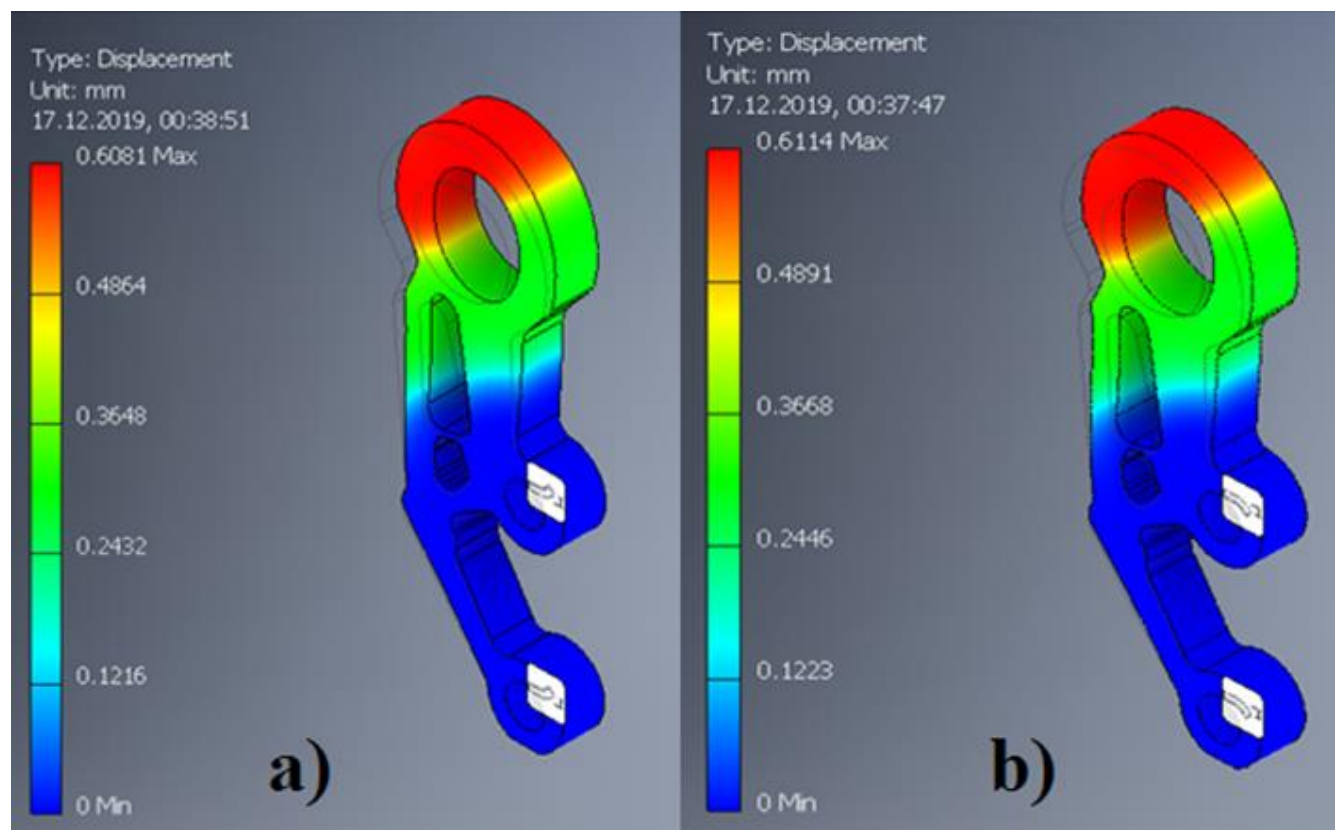

Figure 13. Displacement on the part with finite element analysis after second optimization a) Machining b) additive manufacturing. 
The analysis results obtained at the end of the part optimization of the created design are shown in Table 5. As it can be understood from the table, after optimization, the stress regions that are maximum on the part are no longer punctual with optimizations. According to the program, while the maximum stress values are seen only in a few places before the first optimization, after the optimization the stresses show a homogeneous distribution in the area where the force is applied.

Table 5. Analysis results after second optimization.

\begin{tabular}{|c|c|c|c|c|c|}
\hline \multicolumn{3}{|c|}{ MACHINING ANALYSIS RESULTS } & \multicolumn{3}{|c|}{ ADDITIVE MANUFACTURING ANALYS IS RES ULTS } \\
\hline Name & Minimum & Maximum & Name & Minimum & Maximum \\
\hline Volume & $72476.3 \mathrm{~mm}^{\wedge} 3$ & & Volume & $72476.3 \mathrm{~mm}^{\wedge} 3$ & \\
\hline Mass & $0.112 \mathrm{~kg}$ & & Mass & $0.112 \mathrm{~kg}$ & \\
\hline \begin{tabular}{|l} 
Von Mises Stress \\
\end{tabular} & $0.012 \mathrm{MPa}$ & $20.612 \mathrm{MPa}$ & Von Mises Stress & $0.010 \mathrm{MPa}$ & $21.297 \mathrm{MPa}$ \\
\hline 1st Principal Stress & $-2.812 \mathrm{MPa}$ & $23.573 \mathrm{MPa}$ & 1st Principal Stress & $-2.457 \mathrm{MPa}$ & $23.727 \mathrm{MPa}$ \\
\hline 3rd Principal Stress & $-10.966 \mathrm{MPa}$ & $2.782 \mathrm{MPa}$ & 3rd Principal Stress & $-10.575 \mathrm{MPa}$ & $3.409 \mathrm{MPa}$ \\
\hline Displacement & $0.000 \mathrm{~mm}$ & $0.608 \mathrm{~mm}$ & Displacement & $0.000 \mathrm{~mm}$ & $0.608 \mathrm{~mm}$ \\
\hline Safety Factor & $2.523 \mathrm{ul}$ & $15.000 \mathrm{ul}$ & Safety Factor & $1.362 \mathrm{ul}$ & $15.000 \mathrm{ul}$ \\
\hline Stress XX & $-10.024 \mathrm{MPa}$ & $7.410 \mathrm{MPa}$ & Stress XX & $-9.973 \mathrm{MPa}$ & $7.777 \mathrm{MPa}$ \\
\hline Stress XY & $-8.971 \mathrm{MPa}$ & $8.118 \mathrm{MPa}$ & Stress XY & $-8.881 \mathrm{MPa}$ & $7.681 \mathrm{MPa}$ \\
\hline Stress XZ & $-1.879 \mathrm{Mpa}$ & $1.419 \mathrm{MPa}$ & Stress XZ & $-1.546 \mathrm{MPa}$ & $1.352 \mathrm{MPa}$ \\
\hline Stress YY & $-6.913 \mathrm{MPa}$ & $22.394 \mathrm{MPa}$ & Stress YY & $-6.689 \mathrm{MPa}$ & $22.638 \mathrm{MPa}$ \\
\hline Stress YZ & $-1.433 \mathrm{MPa}$ & $1.380 \mathrm{MPa}$ & Stress YZ & $-1.481 \mathrm{MPa}$ & $1.429 \mathrm{MPa}$ \\
\hline Stress ZZ & $-3.986 \mathrm{MPa}$ & $5.259 \mathrm{MPa}$ & Stress ZZ & $-3.650 \mathrm{MPa}$ & $5.752 \mathrm{MPa}$ \\
\hline X Displacement & $-0.025 \mathrm{~mm}$ & $0.427 \mathrm{~mm}$ & X Displacement & $-0.026 \mathrm{~mm}$ & $0.427 \mathrm{~mm}$ \\
\hline Y Displacement & $-0.010 \mathrm{~mm}$ & $0.470 \mathrm{~mm}$ & Y Displacement & $-0.010 \mathrm{~mm}$ & $0.470 \mathrm{~mm}$ \\
\hline Z Displacement & $-0.023 \mathrm{~mm}$ & $0.024 \mathrm{~mm}$ & Z Displacement & $-0.023 \mathrm{~mm}$ & $0.023 \mathrm{~mm}$ \\
\hline Equivalent Strain & $0.000 \mathrm{ul}$ & $0.010 \mathrm{ul}$ & Equivalent Strain & $0.000 \mathrm{ul}$ & $0.010 \mathrm{ul}$ \\
\hline 1st Principal Strain & $0.000 \mathrm{ul}$ & $0.011 \mathrm{ul}$ & 1st Principal Strain & $0.000 \mathrm{ul}$ & $0.011 \mathrm{ul}$ \\
\hline 3rd Principal Strain & $-0.007 \mathrm{ul}$ & $-0.000 \mathrm{ul}$ & 3rd Principal Strain & $-0.007 \mathrm{ul}$ & $-0.000 \mathrm{ul}$ \\
\hline Strain XX & $-0.006 \mathrm{ul}$ & $0.003 \mathrm{ul}$ & Strain $\mathrm{XX}$ & $-0.006 \mathrm{ul}$ & $0.003 \mathrm{ul}$ \\
\hline Strain XY & $-0.007 \mathrm{ul}$ & $0.006 \mathrm{ul}$ & Strain XY & $-0.007 \mathrm{ul}$ & $0.006 \mathrm{ul}$ \\
\hline Strain XZ & $-0.001 \mathrm{ul}$ & $0.001 \mathrm{ul}$ & Strain XZ & $-0.001 \mathrm{ul}$ & $0.001 \mathrm{ul}$ \\
\hline Strain YY & $-0.004 \mathrm{ul}$ & $0.010 \mathrm{ul}$ & Strain YY & $-0.004 \mathrm{ul}$ & $0.010 \mathrm{ul}$ \\
\hline Strain YZ & $-0.001 \mathrm{ul}$ & $0.001 \mathrm{ul}$ & Strain YZ & $-0.001 \mathrm{ul}$ & $0.001 \mathrm{ul}$ \\
\hline Strain ZZ & $-0.004 \mathrm{ul}$ & $0.002 \mathrm{ul}$ & Strain ZZ & $-0.004 \mathrm{ul}$ & $0.001 \mathrm{ul}$ \\
\hline
\end{tabular}

\subsection{Preparation of Samples}

As a result of the analysis and optimizations made in the program, the production phase of the parts started. Parts produced with CNC Router for machining are shown in figure 14.

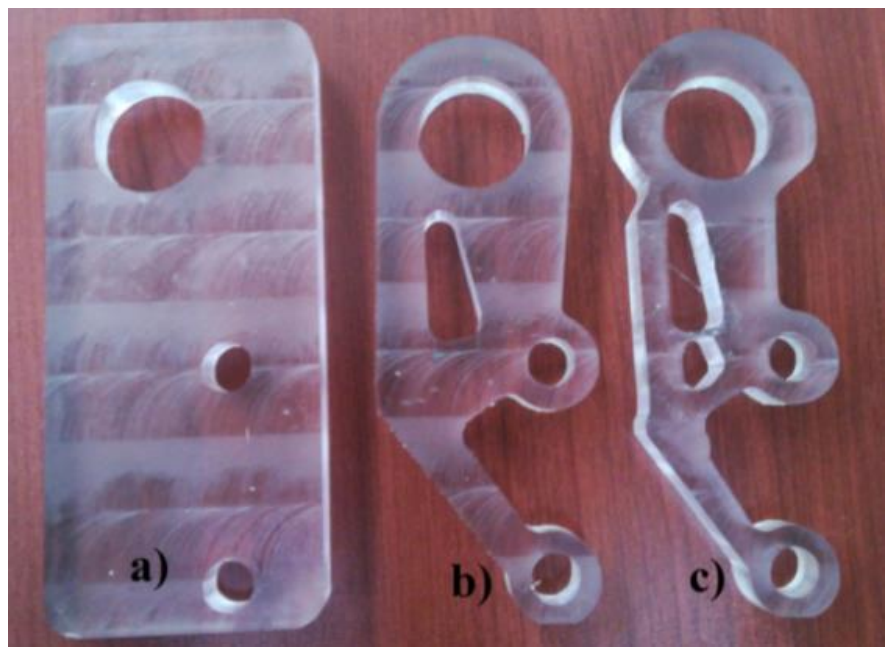

Figure 14. Parts produced with CNC Router

a) conceptual model, b) first optimization, c) second optimization. 
The samples produced by additive manufacturing were made by heated bed to $50^{\circ} \mathrm{C}$, using a layer height of 150 microns, $100 \%$ infill percentage and Pet-G filament. Samples produced by additive manufacturing method are shown in figure 15.

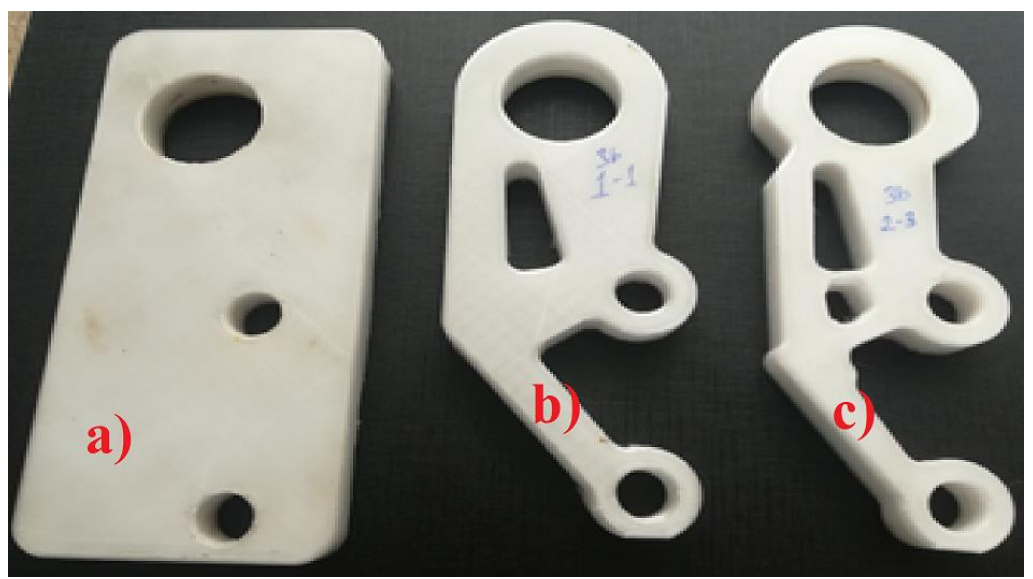

Figure 15. 3D printed parts

a) Conceptual model, b) first optimization, c) second optimization.

\subsection{Tensile Test}

In the tensile test, the infill rate of the samples printed with a 3D printer is important. As the infill rate increases, the load to be carried by the samples increases [14-15]. In addition, the fact that the printer used is a closed or open system changes the mechanical properties of the samples. Polymers have variable mechanical elongation rates due to their structure. The mechanical properties may vary due to factors such as age, storage and weather conditions. [13-15]. In this study, the samples have been printed with a $100 \%$ infill rate and an open system printer has been used. Figure 16 shows all the samples produced and applied the tensile test.

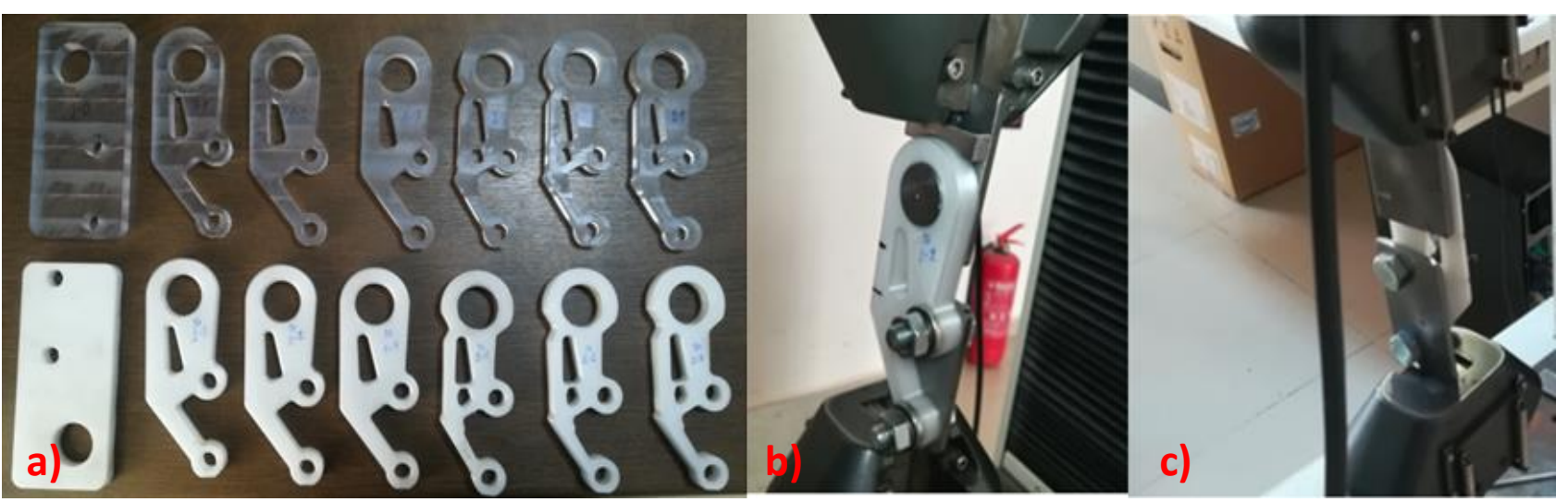

Figure 16. a) All tensile samples b) Wiew of front during tensile test c) Back side wiew during tensile test.

\section{RESULTS}

\subsection{Mass Measurement}

Since the amount of mass is an important factor, measurements have been made with an analytical balance. The mass in the design software is approximately $303(0.303 \mathrm{~kg})$ grams before optimization, as can be seen in Table 5. At the end of the optimization, the mass has decreased to approximately 112 $(0.112 \mathrm{~kg})$ grams, in other words, the mass changes have been reduced by $63.09 \%$. As seen in the table, mass values before and after optimization for additive manufacturing and machining are the same in the software. The reason is that only Pet-G material was selected in the program. Therefore, mass and volume did not change for both manufacturing methods in the mass calculation made on the selected material. 
Table 5. Program and actual measured mass and volume values.

\begin{tabular}{|c|c|c|c|c|}
\hline & \multirow{4}{*}{$\begin{array}{c}\text { Volume In The } \\
\begin{array}{c}\text { Program } \\
\left(\mathrm{mm}^{3}\right)\end{array} \\
196409\end{array}$} & \multirow{4}{*}{$\begin{array}{c}\text { Mass In The } \\
\begin{array}{c}\text { Program } \\
(\mathrm{kg})\end{array} \\
0.303\end{array}$} & \multirow{3}{*}{$\begin{array}{c}\text { Mass Measurement in } \\
\text { Reality ( kg ) }\end{array}$} \\
\hline & & & & \\
\hline \multirow[b]{2}{*}{ Conceptual Model } & Machining & & & \\
\hline & $\begin{array}{l}\text { Additive } \\
\text { Manufacturing }\end{array}$ & & & 0.221 \\
\hline \multirow[b]{2}{*}{ First Optimization Post } & Machining & \multirow[b]{2}{*}{90612} & \multirow[b]{2}{*}{0.14} & 0.111 \\
\hline & $\begin{array}{l}\text { Additive } \\
\text { Manufacturing }\end{array}$ & & & 0.1 \\
\hline \multirow[b]{2}{*}{$\begin{array}{l}\text { Second Optimization } \\
\text { Post }\end{array}$} & Machining & \multirow[b]{2}{*}{72476} & \multirow[b]{2}{*}{0.112} & 0.089 \\
\hline & $\begin{array}{l}\text { Additive } \\
\text { Manufacturing }\end{array}$ & & & 0.079 \\
\hline \multirow{2}{*}{$\begin{array}{l}\text { Change Difference / \% } \\
\text { Difference }\end{array}$} & Machining & \multirow{2}{*}{$\begin{array}{c}-123933 \\
(-\% 63.09)\end{array}$} & \multirow{2}{*}{$\begin{array}{c}-0.191 \\
(-\% 63.09)\end{array}$} & $-0.155(-\% 67.5)$ \\
\hline & $\begin{array}{l}\text { Additive } \\
\text { Manufacturing }\end{array}$ & & & $-0.142(-\% 64.05)$ \\
\hline
\end{tabular}

\subsection{Tensile Test}

One sample from the conceptual model, three samples after the first optimization and three samples after the second optimization have been subjected to tensile tests. Tensile test results for machining are given in Table 6.

Table 6. Machining tensile samples test results.

\begin{tabular}{|c|c|c|c|}
\hline & \multicolumn{3}{|c|}{ Machining } \\
\hline & Conceptual Model & $\begin{array}{c}\text { First Optimization } \\
\text { Post }\end{array}$ & $\begin{array}{c}\text { Second Optimization } \\
\text { Post }\end{array}$ \\
\hline & $\begin{array}{l}\text { Maximum Force } \\
(\mathrm{kN})\end{array}$ & $\begin{array}{c}\text { Maximum Force } \\
(\mathrm{kN})\end{array}$ & $\begin{array}{c}\text { Maximum Force } \\
(\mathrm{kN})\end{array}$ \\
\hline 1.Specimen & 14.009 & 12.169 & 10.616 \\
\hline 2.Specimen & $X$ & 12.169 & 10.891 \\
\hline 3.Specimen & $X$ & 12.147 & 3.656 \\
\hline Average & 14.009 & 12.162 & 10.754 \\
\hline
\end{tabular}

It is seen that the value of the test result for the third sample of the second optimization of machining is very different from the others. This is thought to be due to the specimen not properly attached to the tensile grips. The hole axes of the conceptual model are different. Therefore, if the sample is not fixed well, it will be exposed to shearing. For this reason, as soon as the tensile test started, the sample has been broken and a different result has been obtained from the other tensile results. The $3.656 \mathrm{kN}$ value in the table was not included when calculating the average values. Tensile tests have been carried out under the same conditions for samples produced with the 3D printer. Tensile test results are given in Table 7 .

Table 7. Additive manufacturing tensile specimens test results.

\begin{tabular}{|c|c|c|c|}
\hline & \multicolumn{3}{|c|}{ Additive Manufacturing } \\
\hline & Conceptual Model & $\begin{array}{c}\text { First Optimization } \\
\text { Post }\end{array}$ & $\begin{array}{c}\text { Second Optimization } \\
\text { Post }\end{array}$ \\
\hline & $\begin{array}{c}\text { Maximum Force } \\
(\mathrm{kN})\end{array}$ & $\begin{array}{c}\text { Maximum Force } \\
(\mathrm{kN})\end{array}$ & $\begin{array}{c}\text { Maximum Force } \\
(\mathrm{kN})\end{array}$ \\
\hline 1.Specimen & 8.775 & 7.806 & 7.516 \\
\hline 2.Specimen & $\mathrm{X}$ & 8.203 & 6.813 \\
\hline 3.Specimen & $\mathrm{X}$ & 8.863 & 6.231 \\
\hline Average & 8.775 & 8.291 & 6.853 \\
\hline
\end{tabular}

It is seen that the maximum force values are lower for samples produced by the additive manufacturing method. Comparison of maximum force values before and after optimization and \% differences are given in Table 8. While creating the table, the average of the maximum strength values of the samples subjected to the tensile test has been taken. 
Table 8. Machining and Additive manufacturing tensile specimens test results.

\begin{tabular}{|l|l|c|}
\multicolumn{2}{|l}{} & $\begin{array}{c}\text { Maximum Force } \\
(\mathrm{kN})\end{array}$ \\
\hline \multirow{2}{*}{ Fonceptual Model } & Machining & 14.009 \\
\cline { 2 - 3 } & Additive Manufacturing & 8.775 \\
\hline \multirow{2}{*}{ Second Optimization Post } & Machining & 12.162 \\
\cline { 2 - 3 } & Additive Manufacturing & 8.291 \\
\hline \multirow{2}{*}{ Change Difference / \% Difference } & Machining & 10.754 \\
\cline { 2 - 3 } & Additive Manufacturing & 6.853 \\
\cline { 2 - 3 } & Machining & $-3.255(-\% 23)$ \\
\cline { 2 - 3 } & Additive Manufacturing & $-1.922(-\% 21)$ \\
\hline
\end{tabular}

It has been observed that the maximum force values for the conceptual model (before optimization) are higher in both manufacturing methods. The maximum force value for the machining conceptual model design has been $12.161 \mathrm{kN}, 10.753 \mathrm{kN}$ for the first optimization, and $14.009 \mathrm{kN}$ for the second optimization. In additive manufacturing, the maximum force value has been obtained as $8,775 \mathrm{kN}$ for the conceptual model (before optimization), 8,291 $\mathrm{kN}$ for the first optimization, and 6,853 kN for the second optimization.

The maximum force value decreases in both manufacturing methods at the end of the first optimization. This is also an expected situation. This is thought to be due to the narrowing of the material crosssections at the end of the first optimization. Since the samples are initially required to carry a load of 2 $\mathrm{kN}$, this does not create any negative consequences. It has been observed that weight reduction and material savings are successful with the optimization made.

According to the finite element analysis, von Mises stresses and displacement values of the machining and additive manufacturing designs before and after optimization are given in Table 9. The preoptimization regional stresses are no longer regional at the end of the optimization. In addition, it is seen that the maximum displacement value for additive manufacturing before optimization is close to $2 \mathrm{~mm}$, but it decreases at the end of the optimization. While there is a difference in the amount of displacement before optimization between the two manufacturing methods, values close to each other have been obtained after the optimization.

Table 9. Von Mises stress and displacement results on the program.

\begin{tabular}{|l|l|c|c|c|c|}
\cline { 3 - 6 } \multicolumn{2}{c|}{} & \multicolumn{2}{c|}{ Von Mises Stress ( Mpa ) } & \multicolumn{2}{c|}{ Displacement ( mm ) } \\
\cline { 3 - 6 } \multicolumn{2}{c|}{ Conceptual Model } & Minumum & Maximum & Minumum & Maximum \\
\hline \multirow{2}{*}{ First Optimization Post } & Machining & 0.008 & 8.775 & 0.000 & 0.327 \\
\cline { 2 - 6 } & Additive Manufacturing & 0.024 & 25.351 & 0.000 & 2.049 \\
\cline { 2 - 6 } & Machining & 0.008 & 14.120 & 0.000 & 0.446 \\
\cline { 2 - 6 } Second Optimization Post & Additive Manufacturing & 0.011 & 14.013 & 0.000 & 0.447 \\
\cline { 2 - 6 } & Machining & 0.012 & 20.612 & 0.000 & 0.608 \\
\cline { 2 - 6 } & Additive Manufacturing & 0.010 & 21.297 & 0.000 & 0.608 \\
\hline
\end{tabular}

Additive manufacturing tensile test samples show brittle fractures. Tensile tests have lasted between 80 and 136 seconds, resulting in sample breakage. However, the machining samples have shown ductile behavior during the tensile test. The stroke value of the tensile test machine has not been sufficient to break the machining samples. In one of the tests, the tensile test machine gave a warning and the test was terminated before the sample broke. Tensile tests of machining samples have taken between 270 and 500 seconds.

\section{CONCLUSION}

In this study, which was carried out to reveal the differences between manufacturing methods using minimum material and time today, it is aimed to research the mechanical and physical properties of Pet$\mathrm{G}$ material after additive manufacturing and machining and to reveal the difference of which one is more 
advantageous. During the optimization steps, the cross-sections on the designs decrease and the stress increases without changing the applied force. Before and after optimization, the samples carry the desired load and the maximum force values obtained from the tensile test confirm this. The ability of software in analysis and optimization processes shortens the production and design time.

Additive manufacturing machines do not require an operator during production. This saves businesses a great cost. But in machining, an operator has to control the production of the machine continuously. In addition, consumables and tools used in machining have to be changed periodically, which increases production costs. Additive manufacturing provides ease of production in the production of complex parts. Therefore, thanks to various topology optimization software, part masses can be reduced more and lighter parts designs can be obtained. In addition, the designer creates more original designs with the additive manufacturing method.

After the optimizations made in this study, the targeted mass reduction has been achieved. After the second optimization, the design has shrunk by approximately $63 \%$ in mass from its initial state, according to the calculation of the software. The mass of the part, which is approximately 300 grams, has been reduced to 100 grams. In addition, the part has shrunk at the same rate in terms of volume. In applications where the mechanical strength is suitable for the material produced by both methods, the additive manufacturing method is more suitable in terms of both material savings and practicality.

\section{REFERENCES}

1. Erçetin, A., Aslantaş, K. and Perçin, M., "Micro milling of tungsten-copper composite materials produced through powder metallurgy method: Effect of composition and sintering temperature", Journal of the Faculty of Engineering and Architecture of Gazi University, Vol 33, No. 4, Pages 1369-1381, 2018.

2. Erçetin, A., Aslantaş, K., Özgün, Ö., "Micro-end milling of biomedical TZ54 magnesium alloy produced through powder metallurgy", Machining Science and Technology, Vol 24, No.6, Pages 924-947, 2020.

3. Tezel, T., Topal, E.S., Kovan, V., "Hybrid manufacturing: an examination of the combination of additive manufacturing and machining methods", International Journal of 3D Printing Technologies and Digital Industry, Vol. 2, Issue 3, Pages 60 - 65, 2018.

4. Koda, Y., Çelebi, A., "Endüstri 4.0 Çerçevesinde Katmanli İmalatta Sensör Uygulamalari", International Journal of 3D Printing Technologies and Digital Industry, Vol 5, Issue 2, Pages 85-97, 2021.

5. Çelebi, A., "Investigation of fused deposition modeling processing parameters of 3d PLA specimens by an experimental design methodology", Materials Testing, Vol 61, No. 5, Pages 405-410, 2019.

6. Börklü, H. R., "Mühendislik Tasarımı Sistematik Yaklaşım”, Sayfa 155-432, Hatiboğlu Basım ve Yayım, Ankara, 2010.

7. Yaban, E., "Bir Uçağın Basınç Duvarının Yapısal Optimizasyonu", [Structural Optimization of an Aircraft Pressure Wall], [Thesis in Turkish], Gazi Üniversitesi, Ankara, 2012.

8. Teach engineering, [ article in English], https://www.teachengineering.org/activities/view/cub creative activity1, September 3, 2021.

9. Pahl, G., Beitz, W., Feldhusen, J., Grote, K. H., "Engineering Design”, 3rd, Edition, Springer Verlag, London, 2007.

10. Mayda, M., "Yeni Bir İnovatif Kavramsal Tasarım İşlem Modeli”, [A New Innovative Conceptual Design Process Model], [Thesis in Turkish], Gazi Üniversitesi, Ankara, 2013.

11. Badır, M. E., "Uydu Ekipmanlarına Yönelik Topoloji Optimizasyon Metodu İle Parça Geometrisi Tasarımı, Modellenmesi, Seçici Lazerle Ergitme Yöntemi İle Üretimi Ve Analizi”, [Part Geometry Design for Satellite Equipment with Topology Optimization Method], [Thesis in Turkish], Gazi Üniversitesi, Ankara, 2019. 
12. Product Development with Topology Optimization Approach., https://www.poligonmuhendislik.com/blog/urun-gelistirme/topolojioptimizasyonu-yaklasimi-ile-urungelistirme , 06 Ekim 2021.

13. Çalışkan, B., "Bir Ticari Taşıtın Makas Gözü Bağlantı Parçasının Optimizasyonu Ve Yapısal Analizler İle Tasarımın Doğrulanması", [Optimization and Design Verification of a Commercial Vehicle's Truss Fixing Part with Structural Analysis], [Thesis in Turkish], İstanbul Teknik Üniversitesi, İstanbul, 2018.

14. Topaç, M. M., Bahar, E., Kaplan, A., Sarıkaya, E. Z., "Lower wishbone design for military vehicle independent front suspension with the aid of topology optimization". IDEFIS 2017: 2nd International Defence Industry Symposium, Pages 333-342, Kırıkkale, 2017.

15. Von Mises Stretch, http://www2.isikun.edu.tr/personel/ahmet.aran/, 10 Aralık 2020.

16. Evlen, H., "Investigation of the Effects of Fill Ratio on the Mechanical Properties of TPU and TPE Samples Produced in 3D Printer", DEUFMD, Vol. 21, Issue 63, Pages 793-80, 2019.

17. Evlen, H., Erel, G., Y1lmaz, E., "Investigation of the Effect of Occupancy Rate on Part Strength in Open and Closed Systems", Politeknik Dergisi Vol.21, Issue 3, Pages 651-662, 2018.

18. Özsoy, K, Şentürk, E, Aydoğan, D , Korucu, Ö ., "3B Yazıcı Teknolojisi için Topoloji Optimizasyonu: N95 Maske Üzerine Bir Çalışma". Türk Doğa ve Fen Dergisi, 9, 152-159, 2020. 